\title{
PERCEPTIONS OF NURSING ALUMNI REGARDING THE COURSE CONTRIBUTION IN PROVIDING HEALTH CARE
}

\author{
Elza de Fátima Ribeiro Higa', Romeu Gomes², Maria Helena Ribeiro de Carvalho ${ }^{3}$, Ana Paula Ceolotto \\ Guimarães ${ }^{4}$, Elane de Fátima Taipeiro ${ }^{5}$, Maria de Lourdes Marmorato Botta Hafner ${ }^{6}$, Sebastião Marcos Ribeiro \\ de Carvalho ${ }^{7}$
}

${ }^{1}$ Ph.D. in Nursing. Professor of the Nursing and Medicine Courses and of the Professional Master's Program at Faculdade de Medicina de Marília (Famema). São Paulo, Brazil. E-mail: hirifael@gmail.com

${ }^{2}$ Ph.D. in Public Health. Senior Researchers and Adjunct Coordinator of Instituto Fernandes Figueira, Fundação Oswaldo Cruz. CNPq researcher. São Paulo, Brazil. E-mail: romeu@iff.fiocruz.br

${ }^{3}$ Ph.D. in Nursing. Professor of the Nursing Course at Famema. São Paulo, Brazil. E-mail: nucleodeavaliacao@famema.br

${ }^{4}$ Ph.D. in Pharmacology and Pain. Professor of the Nursing and Medicine Courses at Famema. São Paulo, Brazil. E-mail: apceolottog@yahoo.co.uk

${ }^{5}$ Ph.D. in Sciences. Professor of the Nursing and Medicine Courses at Famema. São Paulo, Brazil. E-mail: nucleodeavaliacao@ famema.br

${ }^{6}$ MD. Academic and University Administration Specialist. Professor of the Medicine Course at Famema. São Paulo, Brazil. E-mail: nucleodeavaliacao@famema.br

${ }^{7}$ Master in Evidence Based Medicine. Professor at Universidade Estadual Paulista - Marília Campus. São Paulo, Brazil. E-mail: nucleodeavaliacao@famema.br

\begin{abstract}
This present study evaluated nursing education based on problem-solving and learning based on problems originating from alumni's perceptions. This is an ex-post-facto cross-sectional study. Results were analyzed using both quantitative and qualitative approaches triangulation and through dialectical hermeneutics. In the quantitative approach 180 alumni answered a questionnaire. The qualitative approach involved 14 interviews that searched for meanings related to the notion of ideal care, in order to build indicators that would reveal this evaluation logic. These indicators guided the choice of triangulation questions. Results demonstrated that $85.1 \%$ of alumni are working in the nursing market, $92.1 \%$ have taken a post-graduate course and $99.1 \%$ believe they have the education required to deliver ethical, humanized and founded care. Data analysis demonstrates a compromised education as autonomy and knowledge are being built, and articulated to the Single Health System and the world nursing principles.
\end{abstract}

DESCRIPTORS: Evaluation. Nursing care. Comprehensiveness.

\section{PERCEPÇÃO DO EGRESSO DE ENFERMAGEM SOBRE A CONTRIBUIÇÃO DO CURSO PARA O EXERCÍCIO DO CUIDADO}

RESUMO: O estudo avaliou a formação em enfermagem ancorada na problematização e na aprendizagem baseada em problemas a partir da percepção dos egressos. Trata-se de estudo transversal de natureza ex-post-facto. Os resultados foram analisados na triangulação das abordagens quantitativa e qualitativa e na perspectiva hermenêutica dialética. Na abordagem quantitativa 180 egressos responderam um questionário. Na qualitativa, 14 participaram das entrevistas, que buscaram sentidos relacionados ao cuidado ideal, para construção dos indicadores que revelassem a lógica da avaliação. Esses indicadores nortearam a escolha das questões para triangulação. Os resultados apontaram que $85,1 \%$ dos egressos estão inseridos no mercado de trabalho, 92,1\% cursaram pós-graduação e 99,1\% acreditam apresentar formação necessária ao cuidado ético, humanizado e fundamentado. A análise dos dados aponta para formação comprometida com a construção da autonomia e do conhecimento, bem como articulada aos princípios do Sistema Único de Saúde e do mundo do trabalho em enfermagem.

DESCRITORES: Avaliação. Cuidado em enfermagem. Integralidade.

\section{LA PERCEPCIÓN DE LOS GRADUADOS EN ENFERMERÍA SOBRE LA CONTRIBUCIÓN DEL CURSO PARA EL EJERCICIO DEL CUIDADO.}

RESUMEN: El estudio objetivó evaluar los resultados de la formación en enfermería anclada en la problematización y en el aprendizaje basado en problemas desde la percepción de los propios egresados. Estudio transversal y de naturaleza ex-post-facto. Los resultados fueron analizados en por la triangulación de métodos cuantitativos y cualitativos y la perspectiva hermenéutica dialéctica. En el abordaje cuantitativo 180 egresados respondieron un cuestionario. En el cualitativo, 14 participaron de entrevistas, relatando sus pensamientos relacionados al cuidado ideal, para la construcción de indicadores que revelasen la lógica de la evaluación. Esos indicaron nortearon las cuestiones para la triangulación. Los resultados mostraron: 85,1\% de los graduados están en el mercado laboral, 92,1\% asistieron al posgrado y 99,1\% creen presentar una formación necesaria al cuidado ético, humanizado y fundamentado. Los datos resaltan una formación comprometida con la construcción de autonomía y conocimiento y articulada a los principios del Sistema Único de Salud y del mundo laboral en enfermería.

DESCRIPTORES: Evaluación. Cuidados de enfermería. Integralidad. 


\section{INTRODUCTION}

Economic, scientific and technological advances result in educational policy changes and propel the search for new understandings in the working market. ${ }^{1}$ In Brazil, health area transformations are associated with alterations in the population's epidemiologic profile and with the consolidation process of the Unified Health System (SUS as per its acronym in Portuguese), where principles and guidelines must ensure public, social and economic policies that will secure the population's physical, mental and social welfare. These aspects are taken into account in the Brazilian National Curriculum Guidelines for courses in the health area. ${ }^{2}$ Under this context, education should, by problem-solving and meaningful learning, lead to critical thinking about reality, giving priority to the dialogical education practice of developing autonomy, responsibility of professionals and the transformation of reality. ${ }^{3-4}$

In response to the need for educational changes, the Marília Faculty of Medicine (Faculdade de Medicina de Marília, Famema as per its acronym in Portuguese) proposes education articulated to the working scope, adopting a broader reaching pedagogical project that, in addition to the techno-scientific domain of the profession, assumes a political commitment to improving the population's quality of life based on care comprehensiveness. Hence, the nursing course adopts an integrated and dialogical competency-guided curriculum, where learning originates from the working scope, critically, reflexively and humanly, building professional practice in accordance to SUS and the national guidelines and ideals. ${ }^{5}$

In order for the changes to be effective there was also a diversification of teaching/ learning scenarios, as follows: Community Interaction (CI), comprised of activities developed with medical and nursing students, within the Family Health Program (FHP) area, through the use of reality problem-solving; and Professional Abilities (PA), which developed semiology and communication abilities. As of 2003, they were both reorganized, respectively, into the Professional Practice Unit (PPU) and Professional Practices Laboratory (PPL), based on the learning strategy of problem-solving methodology. In 2001 the Systematized Educational Unit (SEU) was introduced, developed by Problem-Based
Learning (PBL). PPU is developed within the four modules of the course and SEU within the first two. ${ }^{5}$

This curriculum structure, developed by active methodologies, provides an opportunity for meaningful learning, occurring when students relate the new information to the meanings of the network they already have and that constitute their cognitive structure. While learning this, they assimilate meanings related to the new content. It gives priority to the articulation between theory and practice and the connection among students, patients and the multidisciplinary team, stimulating the development of communication, clinical reasoning, personal inter-relational abilities and a sense of responsibility, as it enables interventions in different care situations. These interventions include, among other aspects, a change in the concept of care centered on techniques and procedures for a practice that will broaden the development of relationships and attitudes respecting human beings' inter-subjectivity, as predicted for the professional profile in the Famema Nursing Course Pedagogical Project. ${ }^{5}$

Under this perspective, health care includes a philosophical view, where it is understood as an existential element allowing for selfunderstanding and reconstruction of the human condition continuously and simultaneously, requiring a practical attitude in light of the fact that health interventions may acquire different meanings in various situations. ${ }^{6-7}$ This care mode signals the need for broadening nurses' views about the care environment micro-spaces, resulting in a systemic focus capable of dialoguing all different existential and professional dimensions with the intent to improve the population's quality of life. ${ }^{8}$

Analyzing alumni's perceptions about the contribution of their course is fundamentally important, promoting a dialogue between education and practice. This dialogue between educational strategies and the reality in which work takes place may guide thought regarding the changes needed to reach the recommended professional profile set out by the Brazilian National Curriculum Guidelines for nursing graduates.

Bearing this information in mind, this present study has the objective to evaluate, from the alumni's perception, the contribution of the Course in their education and the performance of the profession as proposed by Famema. 


\section{METHODOLOGICAL TRAJECTORIES}

This present study was approved by the Research Ethics Committee at Famema, under protocol No. 087, following the precepts of Resolution 196/96 of the National Council of Health. Participants signed a Free and Informed Consent Form prior to the beginning of data collection. ${ }^{9}$

This is a cross-sectional study, ex-post-facto, utilizing both quantitative and qualitative approaches, which are complementary when approaching a reality with a view to better understanding it. ${ }^{10}$ Results were analyzed by a methods triangulation proposal and by articulating multiple perspectives and information. ${ }^{11-12}$

\section{Quantitative evaluation}

A questionnaire was addressed to alumni from the classes of 2001 and 2006. It was composed of 37 questions related to socio-economic aspects, continuing education, exercising the profession, professional insertion and course evaluation under the alumni's point of view. The questionnaire was available on-line, through e-mail or by direct mail for the 180 alumni that composed $75 \%$ of the classes' total. Data collection in this stage was performed during a twomonth period between April and May of 2008. Information was inserted into a data base, using the EPINFO software.

For "course evaluation" 16 questions were employed; the answers were structured by the Likert scale, ${ }^{13}$ specifying the level of agreement with each statement regarding the course contribution, as follows: strongly disagree $(\mathrm{SD})=1$, disagree $(D)=2$, neither agree nor disagree $(N A N D)=3$, agree $(A)=4$, or strongly agree $(S A)=5$. Data were summarized by the total number of individuals per year studied, in mean, standard deviation (SD), median, minimum value, maximum value, absolute frequencies and percentages.

In the analysis regarding the course evaluation by the alumni, the mean score and the SD was calculated for each question.

The study regarded groups, according to numerical variables, by performing univariate analysis and when results were significant, the multiple comparison SNK test was employed. The Kruskal-Wallis non-parametric variance analysis was employed when the mean scores from the questions regarding the course evaluation were compared.
In order to analyze the answers of the alumni regarding the course evaluation, the $Z$ test for proportions was employed, grouping each assertive answer into three frequency classes. In class formation, the first class, termed "Disagreement", was comprised of the grouping of answers SD + D; the second, termed "non-defined Agreement", by NAND answers and a third class termed "Agreement" was formed by grouping answers A + SA.

The Fisher exact test was employed to study the relationship between the answer proportions for the items studied according to agreement specified and the graduation year.

All tests adopted the significance level of 5\% probability for the rejection of nullity hypothesis. The SPSS software was employed for calculation analysis. ${ }^{14}$

\section{Qualitative evaluation}

Semi-structured interviews were performed throughout the period from May to June of 2008, based on the trajectory after graduation; the contribution of the course towards exercising the profession; the health-client professional relationship; articulations among biological, psychological and social dimensions of the health-illness-care process; and course evaluation.

A convenience sample was built according to the principles of the qualitative approach. ${ }^{12}$ Based on these principles, 14 alumni were interviewed, seven from 2005 since they were the last class from the curricular project predominantly based on problem-solving, and seven from 2006, representing the first class after the inclusion of PBL. Fictional names were used in order to ensure anonymity, according to resolution 196/6 of the National Council of Health. ${ }^{9}$

From the data obtained in the semi-structured interviews, data initially related to the ideal care employed by the nursing professional in the view of the alumni were cut. Qualitative indicators were built to reveal, based on the statements, the ideal pattern of care in order to understand the logic of this evaluation. ${ }^{15}$ These indicators were used as a reference in choosing the answers for performing the triangulation between the quantitative and qualitative approaches.

In order to analyze qualitative data under a hermeneutic-dialectic perspective, principles 
of the sense interpretation method were used, ${ }^{16}$ guided by context interpretation, logical reasoning, actions, and the correlation of data with inter-relations and conjectures, among other analytical items.

From the triangulation perspective, the following interpretative-analytical trajectory was followed: (a) reading of statements, seeking to understand the material compound; (b) identification of the ideas described in the alumni's statements; (c) analysis of meanings attributed to ideal nursing care subjacent to ideas; (d) elaboration of evaluation of qualitative indicators descriptors based on the ideal care characteristics; (e) comparison between indicators and alumni's evaluations; (f) articulated qualitative evaluation with converging questions for qualitative indicators; and (g) elaboration of the interpretative synthesis, based on confronting views, objectives and methodologicaltheoretical reference.

\section{RESULTS}

\section{Alumni characterization}

Of $114(63.33 \%)$ interviewees, 11 (9.7\%) are men and $102(90.3 \%)$ are women; the average age is 27 years, with 24 alumni (21.1\%) from the class of $2001,19(16.7 \%)$ from the class of 2002, $17(15.8 \%)$ from 2003, 19 (16.7\%) from 2004, 13 (11.4\%) from
2005 and 21 (18.4\%) from 2006. Most interviewees had taken or were taking post-graduate courses, while only nine alumni (7.9\%) had not taken any at the time of this study.

Data demonstrated that $97(85.1 \%)$ of the interviewees were working as nurses, while 17 $(14.9 \%)$ declared that they were not working as nurses at the present time. Of the first group, 52 $(46.0 \%)$ worked in the secondary or tertiary care sectors, and 35 (67.3\%) were in assistance and/or management positions.

Of the 14 alumni who participated in the interviews, $12(85.7 \%)$ were females and two $(14.3 \%)$ were males, with an average age of 24.2 years; eight were working in tertiary care, three in primary care and one in the private sector, with an average salary of $R \$ 2,378.27$ (Standard Deviation $(\mathrm{SD})= \pm 1,722.8)$.

\section{Construction of qualitative indicators - meanings attributed to health care}

Initially, based on the data obtained from the interviews and from the sense interpretation method, ${ }^{16}$ an analysis was performed to construct the qualitative indicators. ${ }^{14}$ Meanings attributed to health care were presented and were based on the alumni's judgment regarding ideal health care for the nursing professional, as shown in chart 1 .

Chart 1 - Qualitative indicators: alumni's evaluation reference

\begin{tabular}{|c|c|c|}
\hline $\begin{array}{l}\text { Qualitative } \\
\text { indicators }\end{array}$ & $\begin{array}{c}\text { Descriptors according to } \\
\text { alumni }\end{array}$ & Illustrative statements \\
\hline Humanized care & $\begin{array}{l}\text { Meaning, mainly from the } \\
\text { needs of the person to } \\
\text { be cared for, exercising } \\
\text { sympathy for her by careful } \\
\text { listening and welcoming. }\end{array}$ & $\begin{array}{l}{[. . .] \text { sympathy, putting yourself in their shoes, noticing that the }} \\
\text { person is a human being, with rights.... with a life context [...] } \\
\text { (Cícero). } \\
\text { [...] I can't say what is more important [for care], I believe these two } \\
\text { factors, humanization and scientific knowledge... (Ana). } \\
\text { I think that when caring for another person you must keep in mind } \\
\text { this humanization and humanity issue [...] (Clara). }\end{array}$ \\
\hline Well-founded care & $\begin{array}{l}\text { Meaning a solid and broad } \\
\text { theoretical base to improve } \\
\text { practice. }\end{array}$ & $\begin{array}{l}\text { What I consider more important [...] is to know what you are doing. } \\
\text { When you know why the patient is there and understand the whole } \\
\text { picture; in other words, the pathology, the patient's condition } \\
\text { and the social condition, you have a practical and theoretical } \\
\text { knowledge of everything you have to do (Cleide). } \\
\text { [Have] not only anatomy, physiology, pharmacology knowledge, all } \\
\text { this is important, but I think that for the provision of care it is more } \\
\text { than that [...] You must have a deep psychological knowledge and } \\
\text { what most draws my attention is the social knowledge, the social } \\
\text { conditions in which that person is living (Cibele). }\end{array}$ \\
\hline
\end{tabular}


Quantitative evaluation of converging questions for qualitative indicators

As for qualitative indicators, converging questions for these indicators were selected; each item was compared to the proportion of answers in terms of agreement and disagreement from the classes of 2005 and 2006, and then to the other years as presented in table 1 .

Table 1 - Alumni's course evaluation according to graduation year from the scores attributed to converging questions for qualitative indicators. Marília-SP, 2008

\begin{tabular}{|c|c|c|c|c|c|c|c|c|c|}
\hline \multirow[b]{2}{*}{ Year } & \multirow[b]{2}{*}{$\mathrm{n}^{*}$} & \multirow{2}{*}{$\begin{array}{l}\text { Score } \\
\text { mean }\end{array}$} & \multirow[b]{2}{*}{ SD $†$} & \multicolumn{2}{|c|}{ Cl 95\%‡ } & \multirow[b]{2}{*}{ Median } & \multirow[b]{2}{*}{ Minimum } & \multirow[b]{2}{*}{ Maximum } & \multirow{2}{*}{$\begin{array}{c}\text { Kruskal-Wallis } \\
\text { Test }\end{array}$} \\
\hline & & & & $I^{\S}$ & SL" & & & & \\
\hline 2001 & 24 & 4.5 & 0.6 & 4.2 & 4.7 & 4.6 & 2.0 & 5.0 & \\
\hline 2002 & 19 & 4.4 & 0.6 & 4.1 & 4.7 & 4.2 & 2.0 & 5.0 & \\
\hline 2003 & 18 & 4.4 & 0.6 & 4.1 & 4.7 & 4.3 & 2.0 & 5.0 & \\
\hline 2004 & 19 & 4.5 & 0.5 & 4.2 & 4.7 & 4.3 & 2.0 & 5.0 & $\begin{array}{l}T=.97 \\
p=0.85\end{array}$ \\
\hline 2005 & 13 & 4.5 & 0.4 & 4.3 & 4.7 & 4.5 & 3.0 & 5.0 & \\
\hline 2006 & 21 & 4.3 & 0.5 & 4.1 & 4.5 & 4.4 & 3.0 & 5.0 & \\
\hline Total & 114 & 4.4 & 0.6 & 4.3 & 4.5 & 4.4 & 2.0 & 5.0 & \\
\hline
\end{tabular}

* $\mathrm{n}$ : number of individuals interviewed; † SD = Standard Deviation; † CI: Confidence Interval; § IL: Inferior limit; | | SL: Superior limit.

Statistically significant differences were not observed for the year of graduation according to the indicators studied, and according to the specified agreement. Findings indicate no difference among the years in the quantitative evaluation, allowing for the data to be analyzed as a whole, as shown in table 1.
Table 2 presents the analysis, by agreement category, for the converging questions for the parameters comprising the qualitative indicators (humanized care and well-founded care). The objective is to test the difference between the answers "strongly agree" and "agree".

Table 2 - Alumni's course evaluation considering the total score by mean score (1 to 5$)$, standard deviation and agreement level for questions regarding aspects of health care. Marília-SP, 2008

\begin{tabular}{|c|c|c|c|c|c|c|}
\hline $\begin{array}{l}\text { Qualitative } \\
\text { indicator }\end{array}$ & $\begin{array}{c}\text { Converging quantitative } \\
\text { question }\end{array}$ & $\begin{array}{l}\text { Score } \\
\text { mean } \\
\left(S D^{*}\right)\end{array}$ & $\begin{array}{l}Z \text { test for SA† } \\
\text { X Ał scores } \\
\text { (according to } \\
\text { each item) }\end{array}$ & $\begin{array}{l}\text { SAt+A } \\
(\%)\end{array}$ & NANDT(\%) & $\begin{array}{c}D^{* *}+S D+\dagger \\
(\%)\end{array}$ \\
\hline & $\begin{array}{l}\text { The course prepared students to } \\
\text { establish a patient-nurse/family/ } \\
\text { community relationship. }\end{array}$ & $4.7(0.5)$ & $\begin{array}{l}z^{\| l}=-4.6 \\
p<0.01^{\S}\end{array}$ & $\begin{array}{c}69.3 \quad 29.8 \\
99.1\end{array}$ & $\begin{array}{l}0.9 \\
0.9\end{array}$ & - \\
\hline $\begin{array}{l}\text { Humanized } \\
\text { care }\end{array}$ & $\begin{array}{l}\text { The course prepared students to } \\
\text { identify } \\
\text { individual health issues/needs by } \\
\text { clinical exam and history. }\end{array}$ & $4.6(0.5)$ & $\begin{array}{l}z=-2.4 \\
p=0.01^{\S}\end{array}$ & $\begin{array}{c}59.6 \quad 37.7 \\
97.3\end{array}$ & 2.6 & - \\
\hline
\end{tabular}




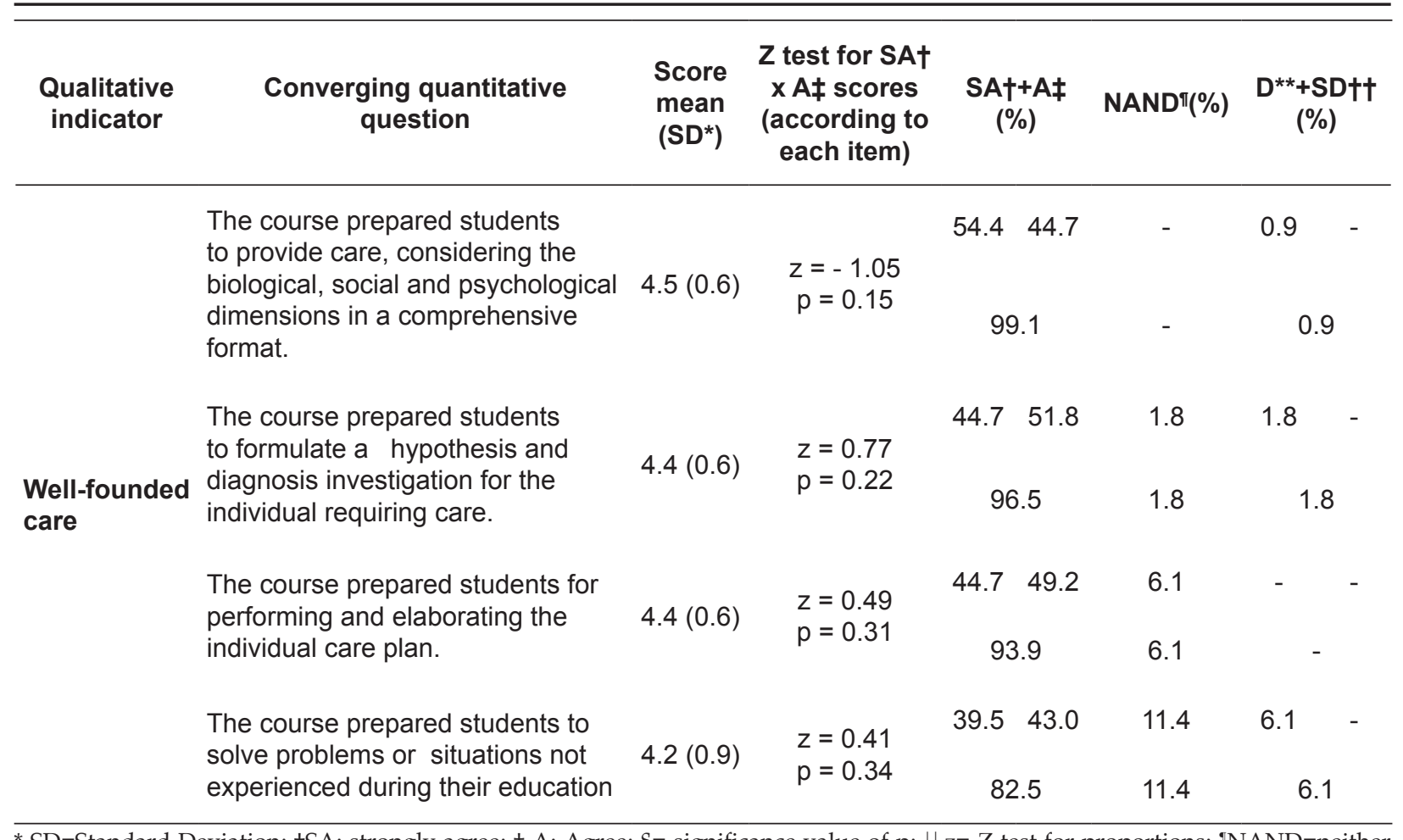

${ }^{*} \mathrm{SD}=$ Standard Deviation; $\nmid S A$ : strongly agree; $\ddagger$ A: Agree; $\S=$ significance value of $\mathrm{p} ;{ }^{\prime \prime} \mathrm{z}=\mathrm{Z}$ test for proportions; ${ }^{\mathrm{N}} \mathrm{NAND}=$ neither agree nor disagree; ${ }^{* *} \mathrm{D}=$ disagree; $\mathrm{\dagger} \mathrm{SD}=$ strongly disagree.

\section{DISCUSSION}

Given the complexity and increasing fragmentation of reality, the elaboration of methodological strategies that will enable a broader understanding of the studied phenomena have been sought by the process of triangulation, enabling researchers to follow the complex thought pattern of research. ${ }^{17}$

Triangulation of qualitative and quantitative data enables a broader view regarding course evaluation from the alumni's perception. Following this perspective from the beginning, it was possible to create a dialogue between the researchers' logic, expressed in the questionnaire format, and the implied logic in the alumni's statements when confronting the notion of ideal health care. These two logics converged, since establishing a relationship between the results of the quantitative and qualitative analysis was possible.

In addition, a dialogue between the interview and the questionnaire enabled us to compare what was idealized by the alumni (qualitative indicators built from statements) to the reality observed by them. Also, a better understanding of the questionnaire provided logic. Therefore, statements transformed into indicators corroborate and enhance the comprehension of the quantitative evaluation.
Results demonstrate that both research approaches yielded a high degree of agreement among alumni regarding the adequacy of the course in the performance of the profession. Alumni reported feeling prepared to meet the professional demands that require, among other aspects, humanized and well-founded care.

The alumni's views about their education, considering care as a central axis of practice, reveal the importance of humanization and well-founded care in terms of both quantitative and qualitative approaches. This importance is reinforced by the agreement indexes in the converging questions for qualitative indicators, which show that the alumni acknowledge these abilities as a contribution of the course.

Considering SUS guidelines and principles, ${ }^{18}$ the Famema nursing professional profile, predicted in its pedagogical project, ${ }^{2}$ is founded on a solid and competent education, capable of developing the humanization of health care. According to the alumni's statements, this is part of their professional practice.

Alumni attributed the acquisition of this knowledge to the opportunity to develop autonomy in their professional practice, since an early insertion in the field allows them to establish interpersonal relationships with their patients, 
families and teams, as well as clinical reasoning skills and theory-practice integration observed in the quantitative and qualitative evaluations and expressed in the following statements. [...] the first year was the basis; there was an internship in a Basic Health Unit and Community Interaction that helped a lot in the contact with the community, and for making house calls... I think it was very good to go to the patients' homes; if you don't respect them, they send you out of their home, got it? (Angelina); [...] I think we have this extra practice to know how to talk to patients. I think it is different. Today, I would evaluate it in a good way (Amanda).

The insertion in care practice from the first year of the course is also pointed out as being a stimulating factor for reflective and critical learning, favoring humanized and well-founded care: [...] there was the PPU, and we didn't like to make the visits. And then the teacher...where is the reflection about your report? What is your feeling? The question of bonding with people in order to care for them, to earn their trust... [...] I have to slowly bond with them... and have a relationship and think about it. Every time I leave my job, I think about it: how could my visit have been different or better? What did I say wrong? What did I say right? How can I improve? That is something I learnt in college (Cláudia).

From the alumni's perception, diversification of practice scenarios for learning articulated to the SEU favors meaningful learning, as well as the development of comprehensiveness and care humanization. As care is delivered under this perspective, in addition to the other's acknowledgement, interaction and the opportunity to open spaces for a dialogical relationship are involved. ${ }^{19}$

In this way, nursing education must meet health and social needs, as emphasized by the SUS, and ensure care comprehensiveness, quality and health care humanization. ${ }^{2}$

Comprehensiveness is built within the professional practice, searching for its transformation through a dialectical process, beginning with self-knowledge and openness to relationships with others. ${ }^{20}$

We begin by realizing that humanized care must be well-founded. As we observe the quantitative questions corresponding to the findings, we can observe that these also tend to acknowledge the effectiveness of the course, favoring the appropriation by alumni of instruments to build important knowledge to favor competent professional practice, as highlighted: what really helped me were the practical internships beginning in the first year. I think this is the greatest difference between Famema and other courses. We can see this even by talking among other nurses. We start by working, having contact with patients, getting used to performing physical exams and administering medication. This practice is already well exercised (Alana).

These aspects also demonstrate that teaching-learning strategies can be used to prepare for the effective exercise of professional practice. Articulation between theory and practice becomes a significant process, providing the needed assurance for performing as a professional. This objective articulation awakens intellectual curiosity and motivates reflective and critical thinking, which are important factors for the comprehension of reality with sound judgment and autonomy: I left college very confident [...]. I have always studied, since the first year, so the reality I found was not so different. As for the care and procedures, I have never had difficulties. With anything. For example, some people are afraid of introducing a nasogastic tube, you know this practical part? (Angélica). From this statement, we can infer that the course utilizes the scientific method, developed while in school and in the PPU and SEU, to develop the necessary knowledge on which to base decision and actions. This perception corroborates the quantitative evaluation that most alumni observed regarding the foundation of their care.

Although a deficiency regarding theoretical knowledge was reported, mainly related to basic aspects of the course, this factor was not acknowledged as being particularly limiting to professional practice: [...] but, on the other hand, I ended up doing well in my professional areas. I have improved and have been in good hospitals, so it is contradictory in the end [...]. So, I mean, we are not behind anyone (Alana).

This contradiction suggests that learning strategies used by the course where "learning to learn" becomes a necessary tool capable of enabling professionals to face different demands and situations. The effectiveness of this strategy emerges when alumni acknowledge that this allows them to search, efficiently and with good judgment, for the knowledge needed to deal with different situations: [...] for me I can't, for example, think of a subject separated from the other subjects, got it? We aggregate. But, at the time, there were too many things to see, but it was a very good thing, I don't criticize it. I bring the question of searching for knowledge with me even today, and every day I search for a new question. But the search is frequent (Artur). Contradictions reported by alumni are 
represented in quantitative results that reveal their successful insertion in the working world and in post-graduate courses.

As the well-founded care indicator is evaluated within the quantitative data, as shown in table 2 , fragility can be noted in the occurrence of some attributions falling within the undefined agreement and disagreement categories, demonstrating the alumni's perception regarding the theoretical base of the course. We understand this fact is a challenge to the improvement of interdisciplinary knowledge construction within all learning scenarios, pointing students towards meaningful theoretical comprehension needed for the development of their professional competence.

Therefore, considering that educational practice is a format of world intervention, it is clear that the teaching-learning process can create opportunities for the construction of knowledge. ${ }^{21}$ In this way, even if some alumni expressed that, while studying, they were unsure of the knowledge they acquired for professional practice, they reported themselves as able to exercise their thoughts, attention and memory, selecting information that could be contextualized within the reality they experienced while working.

\section{CONCLUSION}

Through an interpretative view acquired by triangulation, we demonstrate convergences between data within both research approaches. The analysis confirms the alumni perception regarding the relevance of the strategies developed in the different teaching-learning scenarios.

Among the aspects highlighted as relevant in this study, participants point out the development of abilities and attitudes favoring their actions with autonomy in the exercise of humanized and well-founded care, also pointing out limits and challenges yet to be overcome in relation to theoretical fundamentals.

Keeping in mind the objective of this research and the points raised by the alumni, we can infer that the changes in the teaching-learning process, founded on the Famema pedagogical process, have broken with the technological educational approach based on a hermetic conception of curricular subjects emphasizing the transmission of contents and information, favoring an education founded on the construction of autonomy and articulated knowledge for the working world.
Hence, the philosophical foundations guiding this course, represented among other aspects by Meaningful Learning, Care Comprehensiveness, the National Policy of Humanization and the Professional Competency Guided Curriculum and developed by active teaching-learning methodologies, encourage knowledge development, knowing how to be, and how to make the necessary progress for professional education, consistent with what is recommended and desired by the SUS and the national curriculum guidelines.

The changes adopted in our institution, in the alumni's view, contribute in an expressive way towards humanized and scientifically founded care, providing the required professional competence for the working world.

\section{REFERENCES}

1. Sordi MRL, Bagnato MHS. Subsídios para uma formação crítico-reflexiva na área da saúde: o desafio da virada do século. Rev Latino-am Enfermagem. 1998 Abr; 6(2): 83-8.

2. Ministério da Educação. (BR). Resolução CNE/CES $n^{0} 3$, de 7 de novembro de 2001. Institui diretrizes curriculares nacionais do curso de graduação em enfermagem. Brasília (DF): Diário Oficial da República federativa do Brasil, 9 de Nov. 2001. Seção 1:37.

3. Pessanha RV, Cunha FTS. A aprendizagem-trabalho e as tecnologias de saúde na estratégia da saúde da família. Texto Contexto Enferm. 2009 Abr-Jun; 18(2):233-40

4. Alvim NAT, Ferreira MA. Perspectiva problematizadora da educação popular em saúde e a enfermagem. Texto Contexto Enferm. 2007 Abr-Jun; 16(2):315-9.

5. Faculdade de Medicina de Marília - Famema. Projeto pedagógico do Curso de Enfermagem. Marília: Faculdade de Medicina de Marília; 2008.

6. Heidegger M. Ser e tempo. Petrópolis (RJ): Vozes; 1995.

7. Deslandes SF, organizadora. Humanização dos cuidados em saúde: conceitos, dilemas e práticas. Rio de Janeiro (RJ): Fiocruz; 2006.

8. Backes DS, Sousa FGM, Mello ALSF, Erdmann AL, Nascimento KC, et al. Concepções de cuidado: uma análise das teses apresentadas para um programa de pós-graduação em enfermagem. Texto Contexto Enferm. 2006; 15(Esp):71-8.

9. Ministério da Saúde (BR), Conselho Nacional de Saúde, Comissão Nacional de Ética em Pesquisa. Resolução n ${ }^{0} 196$ de 10 de outubro de 1996: Diretrizes e normas regulamentadoras de pesquisa envolvendo seres humanos. Brasília (DF): MS; 1996. 
10. Minayo MCS, Sanchez O. Quantitativo-qualitativo: oposição ou complementaridade? Cad. Saúde Pública. 1993 Jul-Set; 9(3):39-48.

11. Denzin NK. The research act: a theoretical introduction to sociological methods. Chicago (IL): Aldine Publishing; 1973.

12. Souza ER, Minayo MCS, Deslandes SF, Veiga JPC. Construção dos instrumentos qualitativos e quantitativos. In: Minayo MCS, Assis SG, Souza ER, organizadoras. Avaliação por triangulação de métodos: abordagem de programas sociais. Rio de Janeiro (RJ): Fiocruz; 2005. p. 133-56.

13. Gil AC. Métodos e técnicas de pesquisa social. São Paulo: Atlas; 1987.

14. Statistical Package for the Social Sciences: manual do SPSS [Internet]. Version 13.0. Chicago (Il): SPSS Inc; 2003 [acesso 2008 Mai 10]. Disponível em: http:// www.si.uevora.pt/spss/manual_15.php.

15. Assis SG, Deslandes SF, Minayo MCS, Santos NC. Definição de objetivos e construção de indicadores visando à triangulação. In: Minayo MCS, Assis SG, Souza ER, organizadoras. Avaliação por triangulação de métodos: abordagem de programas sociais. Rio de Janeiro (RJ): Fiocruz; 2005. p. 105-32.

16. Gomes R, Souza ER, Minayo MCS, Malaquias JV, Silva CFR. Organização, processamento, análise e interpretação de dados: o desafio da triangulação. In: Minayo MCS, Assis SG, Souza ER, organizadores. Avaliação por triangulação de métodos: abordagem de programas sociais. Rio de Janeiro (RJ): Fiocruz; 2005. p. 185-221.

17. Souza DV, Zioni F. Novas perspectivas de análise em investigações sobre meio ambiente: a teoria das representações sociais e técnica qualitativa da triangulação de dados. Saúde e Soc. 2003 Jul-Dec; 12(2):76-85.

18. Brasil. Lei $\mathrm{n}^{\circ} 8.080$, de 19 de setembro de 1990. Dispõe sobre as condições para a promoção, proteção e recuperação da saúde, a organização e o funcionamento dos serviços correspondentes, e dá outras providências. Diário Oficial da República Federativa do Brasil, 10 Set 1990. Seção 1: 18055-9.

19. Ayres JRCM. Cuidado e reconstrução das práticas de saúde. Interface Comun Saúde Educ. 2003-2004; 8(14):73-92.

20. Silva KL, Sena RR. A formação do enfermeiro: construindo a integralidade do cuidado. Rev Bras Enferm. 2006 Jul- Ago; 59(4):488-91.

21. Freire P. Pedagogia da Autonomia: saberes necessários à prática educativa. São Paulo (SP): Paz e Terra; 1996. 